\title{
Persepsi PeternakTerhadap Teknologi Pembuatan Telur Asin Menggunakan Alat Pemanas Sederhana
}

\section{(Farmer's Perceptions To The Technology OfMaking Salted Eggs Use Simple Heater)}

\author{
Evita Khoirul Hikmah, Nurdayati, Puji Hartati \\ Program Studi Penyuluhan Peternakan dan Kesejahteraan Hewan \\ Politeknik Pembangunan Pertanian Yogyakarta-Magelang \\ J. Magelang Kopeng Km7, Tegalrejo, Magelang \\ Email : Hikmahk4@gmail.com
}

Diterima : 28 Januari 2019

Disetujui : 19 April 2019

\begin{abstract}
ABSTRAK
Penelitian ini bertujuan untuk mengetahui persepsi peternak terhadap teknologi pembuatantelur asin menggunakan alatpemanassederhana, mengetahuipengaruhfaktor internal (umur, pendidikan, dan pengalaman) dan karakteristik inovasi terhadap persepsi peternak, dan untuk mengetahui karakteristik inovasi memediasi pengaruh faktor internal. Responden yang digunakan pada penelitian ini adalah semua peternak itik petelur di Desa Trasan yang berjumlah 35 orang. Pengujian dilakukan dengan metode deskriptif inferensial menggunakan skala likert pada penentuan persepsi dan analisis data dengan PLS ( Partial Least Square) menggunakan program SmartPLS. Hasil analisis, persepsi peternak terhadap teknologipembuatantelur asin menggunakanalat pemanas sederhanaadalah baikdengan nilai 3085. Hasil perhitungan, model karakteristik inovasi memediasi pengaruh umur terhadap persepsi peternak yang bersifat mediasi penuh (full mediation) $(P<0,05)$ artinya karakteristikinovasi memediasi secara penuh pengaruh umur terhadap persepsi peternak.
\end{abstract}

Kata Kunci: Persepsi Peternak, Teknologi Pembuatan Telur Asin Menggunakan Alat Pemanas Sederhana, Partial Least Square

\section{ABSTRACT}

This study aims to determined breeders 'perceptions of the technology of making salted eggs using a simple heating device, to discover the influence of internal factors (age, education, and experience) and innovation characteristics of breeders' perceptions, and to find out the characteristics of innovation mediating the influence of internal factors. Respondents used in this study were all laying duck breeders in Trasan Village, amounting to 35 people. Testing is done by inferential descriptive method using a Likert scale in determining perception and data analysis with PLS (Partial Least Square) using the SmartPLS program. The results of the analysis, farmers 'perceptions of the technology of making salted eggs using a simple heating device is good with the acquisition of a value of 3085. The results of calculations, innovation characteristic models mediate the effect of age on farmers' perceptions that are full mediation (full mediation) $(P<0.05)$ means that the characteristics innovation fully mediates the influence ofage onfarmers'perceptions.

Keywords: Farmers' Perception, Salted Egg Making Technology Using Simple Heating Equipment, Partial Least Square 


\section{PENDAHULUAN}

Berdasarkan hasil kegiatan identifikasi wilayah di Desa Trasan Jumlah peternak itik petelur sebanyak 35 orang dan populasi ternak itik petelur sebanyak 1455 ekor dengan setiap harinya menghasilkan telur rata-rata sebanyak 500 butir yang digunakan untuk ditetaskan dansebagai telur konsumsi. peternak belum mengolahnya menjadi telur asin secara kontinyu karena kurang tertarik untuk mengusahakan telur asin karena waktu pembuatannya lama, perputaran modalnya kurang efektif dan memerlukan banyak tempat, sehingga muncul teknologi pembuatan telur asin. Teknologi pembuatan telur asin menggunakan alat pemanas sederhana merupakan hal yang baru dan belum pernah disuluhkan bagi peternak di Desa Trasan, sehingga belum diketahui persepsi peternak mengenai teknologi inovasi tersebut. Persepsi peternak terhadap teknologi tidak terlepas dari pengaruh faktor internal (umur, pendidikan, dan pengalaman berusaha tani) dan karakteristik inovasi, sehingga perlu kajian lebih lanjut mengenai persepsi peternak terhadap teknologi pembuatan telur asin menggunakan alat pemanas sederhana yang akan dilaksanakan di Desa Trasan. Peternak dengan faktor internalnya masing-masing melakukan penilaian terhadap karakteristik inovasi dan mempersepsi teknologi inovasi. Hal ini memungkinkan terjadinya efek mediasi karakteristik inovasi antara faktor internal (umur, pendidikan, dan pengalaman berusaha tani) dan persepsi peternak. Tujuan kegiatan pengkajian yaitu sebagai berikut : 1) Mengetahui persepsi peternak, mengetahui pengaruh faktor internal (umur, pendidikan, dan pengalaman berusaha tani) dan karakteristik inovasi terhadap persepsi peternak, dan mengetahui karakteristik inovasi memediasi pengaruh faktor internal (umur, pendidikan, dan pengalaman berusaha tani) terhadap persepsi.

Penyuluhan Pertanian adalah proses pembelajaran bagi pelaku utama serta pelaku usaha agar mereka mau dan mampu menolong dan mengorganisasikan dirinya dalam mengakses informasi pasar, teknologi, permodalan, dan sumber daya lainnya, sebagai upaya untuk meningkatkan produktivitas, efisiensi usaha, pendapatan, dan kesejahteraannya, serta meningkatkan kesadaran dalam pelestarian fungsi lingkungan hidup (Kementrian Pertanian, 2018).

Persepsi peternak terhadap suatu inovasi teknologi merupakan proses pengorganisasian dan interpretasi terhadap stimulus yang diterima oleh peternak, sebelum peternak mengambil keputusan (Fachrista dan Sarwendah, 2014). Menurut Walgito (1990), persepsi memiliki indikator - indikator pengukuran sebagai berikut:a) penyerapan terhadap rangsang atau objek dari luar individu. b) pengertian atau pemahaman dan c) penilaian atau evaluasi. Menurut Schiffman dan Kanuk (2010) suatu teknologi inovasi harus memenuhi sifat karakteristik inovasi untuk diadopsi yaitu keuntungan relatif (relative advantage), tingkat kesesuaian (compability), tingkat kerumitan (complexity), dapat dicoba (triability) dan mudah diamati (observability). 
Metode tekanan osmosis 2017). Menurut Surakitti (2004) faktor yang merupakan upaya untuk meningkatkan mempengaruhi osmosis selain rumus kualitas telur asin, dan diharapkan mampu tekanan osmosis yaitu : suhu akan mempercepat proses pembuatantelurasin, mempengaruhi gerak molekul, ukuran prinsip pemberian tekanan adalah molekul yang terserap, ketebalan meningkatkan perbedaan tekanan osmotik membran, keterlarutan lipid, dan luas antara tekanan di luar dengan tekanan di dalam telur. Semakin tinggi perbedaan tekanan osmotik tersebut, maka semakin permukaan membran.

Berdasarkan landasan teori, tinggi laju difusi $\mathrm{NaCl}$ ke dalam telur (Mulia,

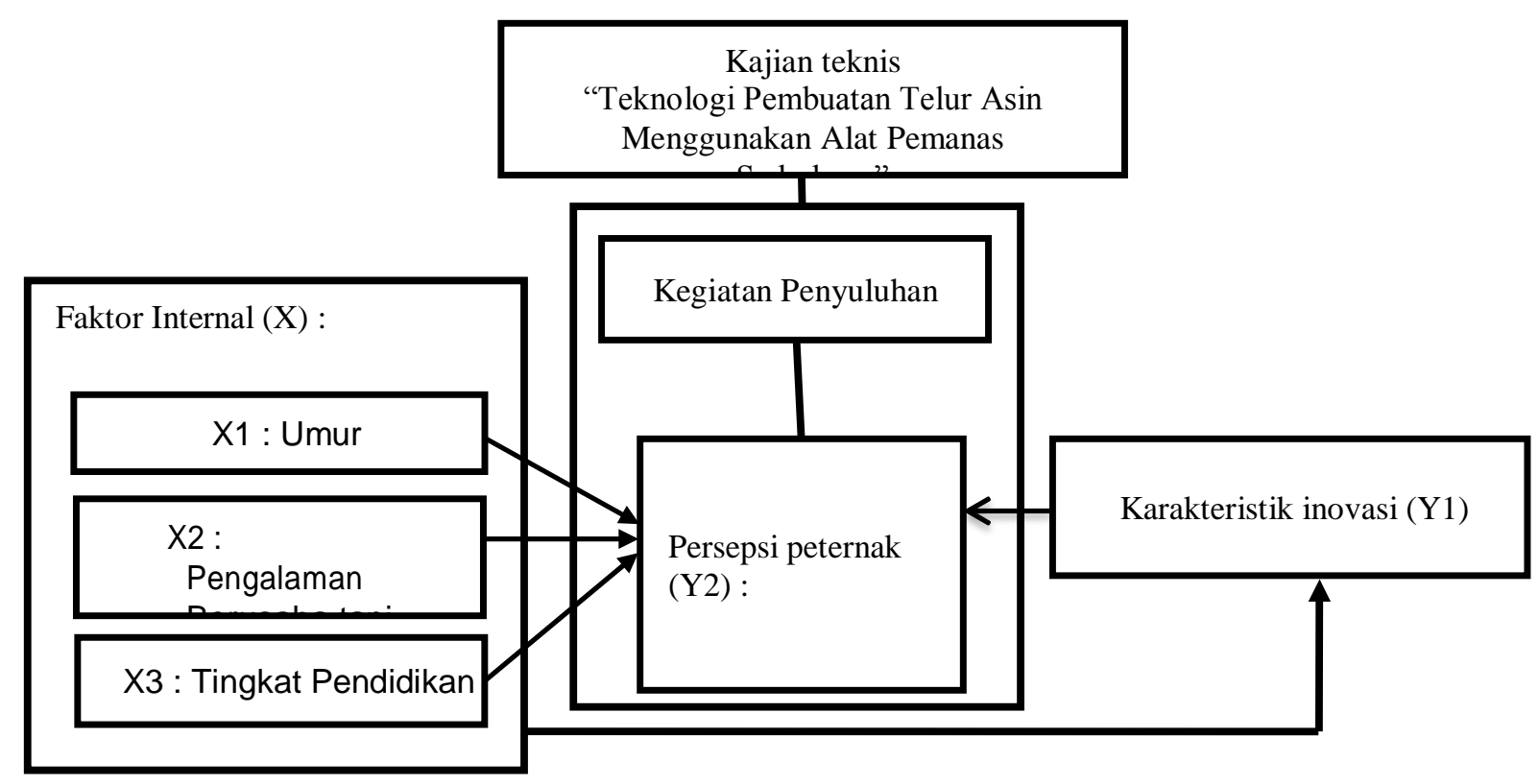

Gambar 1. Skema Kerangka Pikir

\section{MATERI DAN METODE}

Penelitian ini dilaksanakan pada 1 Mei - 30 Juni 2019 di Desa Trasan Kecamatan Bandongan Kabupaten Magelang. Metode pengambilan sampel dengan metode sensus, sampel yang digunakan adalah semua peternak itik petelur yang ada di Desa Trasan sejumlah 35 orang. Jenis pengkajian yang digunakan yaitu deskriptif dilanjutkan inferensial. Data yang diperoleh dari wawancara dan observasi kepada peternak dengan kuesioner yang telah lolos uji validitas dan reliabilitas dianalisis menggunakan analisis deskriptif menggunakan Skala Likert untuk mengetahui persepsi peternak. Dilanjutkan dengan analisis inferensial menggunakan analisis jalur dengan teknik SEM partial least square (PLS) untuk mengetahui pengaruh internal (umur, pendidikan, dan pengalaman berusaha tani) dan karakteristik inovasi terhadap persepsi peternak dan mengetahui karakteristik inovasi memediasi pengaruh faktor internal (umur, pendidikan, dan pengalaman berusaha tani) terhadap persepsi peternak. 
HASIL DANPEMBAHASAN

Persepsi Peternak
Hasil penilaian peternak terhadap karakteristik inovasi tersaji pada tabel 1.

Tabel 1. Hasil Penilaian Peternak Terhadap Karakteristik Inovasi

\begin{tabular}{lrrr}
\hline Aspek & $\begin{array}{r}\text { Item } \\
\text { pertanyaan }\end{array}$ & $\begin{array}{r}\text { Perolehan } \\
\text { nilai }\end{array}$ & Klasifikasi penilaian \\
\hline Keuntungan relatif & 2 & 279 & Baik \\
Tingkat Kesesuaian & 4 & 574 & Baik \\
Tingkat Kerumitan & 2 & 268 & Baik \\
Tingkat dapat dicoba & 4 & 523 & Baik \\
Tingkat Dapat diamati & 4 & 540 & Baik \\
\hline
\end{tabular}

Sumber : Data Terolah, 2019

Berdasarkan Tabel 1. dapat diketahui bahwa peternak menilai bahwa teknologi pembuatan telur asin menggunakan alat pemanas sederhana merupakan teknologi baik, dapat memberikan keuntungan relatif, sesuai dengan keadaan dan kebutuhan peternak, tidak rumit untuk dicoba, dan dapat diamati hasilnya. Sehingga terdapat kemungkinan untuk diadopsi oleh peternak. Hal ini sesuai dengan pendapat Schiffman dan Kanuk (2010) suatu teknologi inovasi harus memenuhi sifat karakteristik inovasi untuk diadopsi yaitu keuntungan relatif (relative advantage), tingkat kesesuaian (compability), tingkat kerumitan (complexity), dapat dicoba (triability) dan mudah diamati (observability).

Persepsi peternak ditentukan dari nilai yang diberikan oleh peternak terhadap tiga indikator pengukuran persepsi yaitu penyerapan/sadar, pemahaman/minat, dan evaluasi/menilai. Hasil penilaian dapat dilihat pada Tabel2.

Tabel 2. Nilai Persepsi Peternak

\begin{tabular}{lrrr}
\hline Indikator & Item pertanyaan & Jumlah responden & Perolehan nilai \\
\hline Penyerapan & 10 & 35 & 1394 \\
Pemahaman & 8 & 35 & 1016 \\
Evaluasi & 5 & 35 & 675 \\
\hline Jumlah & 23 & 35 & 3085 \\
\hline
\end{tabular}

Sumber : Data Terolah 2019

Berdasarkan data pada Tabel2. Klasifikasi perolehan nilaipersepsi disajikan dalam garis kontinum yang dapat dilihat pada Gambar 2.

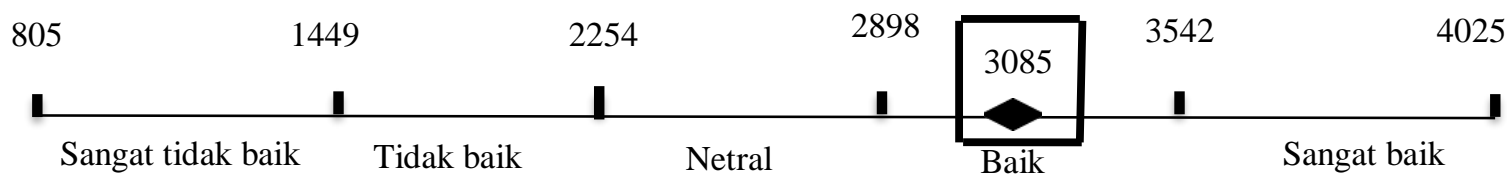

Gambar 2. Garis Kontinum Persepsi Peternak Terhadap Teknologi 
Setelah dilakukan penyuluhan dengan pendekatan kelompok sebanyak 1 kali menggunakan metode ceramah dan diskusi dan pendekatan perorangan sebanyak 1-2 kali menggunakan metode anjangsana dan diskusi. Maka diperoleh nilai sebagaimana Gambar 2. Yang menunjukkan bahwa persepsi peternak terhadap teknologi pembuatan telur asin menggunakan alat pemanas sederhana memperoleh jumlah nilai 3085 dari ketiga indikator pengukuran persepsi. Persepsi peternak terletak pada skala baik. Setelah melalui tahapan penyerapan, pemahaman dan kemudian melakukan evaluasi, peternak menilai bahwa teknologi pembuatan telur asin menggunakan alat pemanas sederhana adalah baik. Peternak itik petelur sudah menilai bahwa teknologi inovasi ini merupakan tekonologi inovasi baru yang dapat membantu pemecahan permasalah usaha taninya. Hal ini sesuai pendapat Alisa (2007) bahwa faktor-faktor fungsional yang menentukan persepsi seseorang berasal dari kebutuhan, pengalaman masa lalu dan hal-hal lain termasuk yang disebut faktor-faktor personal.

2. Pengaruh Faktor Internal dan Karakteristik Inovasi Terhadap Persepsi Peternak

a. Uji Goodness of fit outer model

Penentuan kualitas model pengukuran dilakukan dengan cara menganalisis PLS Alogaritm. Hasil analisis dilihat nilainya pada hasil validitas konvergen, validitas deskriminan, dan uji reliabilitas yaitu : Hasil uji outer loadings menunjukkan skor yang rendah yaitu 0.541 pada pada indikator KI3 (tingkat kerumitan) skor kurang dari 0,70. Pada variabel persepsi, indikator PE (tahap evaluasi) memiliki nilai 0.606 yang kurang dari rule of tumbs 0,70 . Dari hasil ini, dapat disimpulkan bahwa variabel manifest tingkat kerumitan dan variabel manifest tahap evaluasi memiliki validitas konvergen yang kurang baik, sehingga variabel ini dieliminasi dan tidak diikutkan dalam pengujian hipotesis. Hasil uji validitas determinan dapat menjelaskan bahwa nilai AVE pada variabel penelitian memiliki nilai di atas 0,5 , sehingga pengukuran ini dapat di simpulkan memenuhi syarat pengukuran discriminant validity. Hasil uji reliabilitas model menunjukan bahwa hasil dari pengujian composite reliability menunjukan hasil yang baik karena variabel laten seluruhnya telah reliabel karena memiliki nilai composite reliability dan Cronbach's Alpha lebih besar dari 0,7 .

b. Uji Goodness of fit inner model

1) Pengujian R-squared

Output untuk nilai $R^{2}$ yang digunakan yaitu R-square adjusted menggunakan program komputer SmartPLS 3.2.1 yang telah dilakukan dapat dilihat pada Tabel 3.

Tabel 3. Nilai R-Square Adjusted Model

\begin{tabular}{lr}
\hline Matrik & R-Square \\
\hline Karakteristik inovasi & 0.645 \\
Persepsi & 0.637 \\
\hline
\end{tabular}

Sumber : Data terolah, 2019

Nilai predictive - relevance diperoleh dengan rumus: 


$$
\begin{aligned}
& \mathrm{Q}^{2}=1-\left(1-\mathrm{R} 1^{2}\right)\left(1-\mathrm{R}^{2}\right) \ldots . .\left(1-\mathrm{Rp}^{2}\right) \\
& \mathrm{Q}^{2}=1-(1-0,416)(1-0,406)=0,347 \\
& \mathrm{Q}^{2}=0,347
\end{aligned}
$$

Hasil diatas menunjukkan nilai predictive - relevance sebesar 0,347, nilai ini $>0$. Sehingga dapat diartikan bahwa $37,4 \%$ variasi pada variabel persepsi peternak dijelaskan oleh variabel yang digunakan pada model. 62,6\% dijelaskan oleh faktor lainnya diluar model, dengan hasil ini maka disimpulkan model ini memiliki nilai preditif relevan.

2) Pengujian Signifikansi
Nilai T-tabel untuk tingkat kepercayaan sebesar 95\% (a sebesar 5\%) dan derajat kebebasan 35 orang adalah DF $=n-2=35-2=33$ adalah sebesar 2,034. Penentuan pengaruh dari masing-masing variabel ditentukan apabila nilai T-statistics > T-tabel. Pengaruh variabel eksogen terhadap variabel endogen secara langsung

\begin{tabular}{|c|c|c|c|c|c|}
\hline Variabel & $\begin{array}{l}\text { Original } \\
\text { sample } \\
\text { (O) }\end{array}$ & $\begin{array}{l}\text { Sample } \\
\text { mean } \\
(\mathrm{M})\end{array}$ & $\begin{array}{l}\text { Std.deviation } \\
\text { (STDEV) }\end{array}$ & $\begin{array}{l}T \text { statistics } \\
(|\mathrm{O} / \mathrm{STDEV}|)\end{array}$ & $\begin{array}{l}P \\
\text { value }\end{array}$ \\
\hline $\begin{array}{l}\text { Umur } \rightarrow \text { Karakteristik } \\
\text { inovasi }\end{array}$ & -0.210 & -0.215 & 0.170 & 1.235 & 0.218 \\
\hline Umur $\rightarrow$ Persepsi & -0.396 & -0.408 & 0.129 & 3.055 & 0.002 \\
\hline $\begin{array}{l}\text { Pendidikan } \rightarrow \text { Karakteristik } \\
\text { inovasi }\end{array}$ & 0.375 & 0.396 & 0.155 & 2.423 & 0.016 \\
\hline Pendidikan $\rightarrow$ Persepsi & 0.217 & 0.184 & 0.146 & 1.488 & 0.137 \\
\hline $\begin{array}{l}\text { Pengalaman } \rightarrow \text { Karakteristik } \\
\text { inovasi }\end{array}$ & -0.544 & -0.532 & 0.145 & 3.766 & 0.000 \\
\hline Pengalaman $\rightarrow$ persepsi & 0.196 & -0.201 & 0.158 & 1.235 & 0.217 \\
\hline Karakteristik & 0.518 & 0.549 & 0.151 & 3.444 & 0.001 \\
\hline
\end{tabular}
dapat dilihat pada Tabel 4.

Tabel 4. Hasil Path Coefficients

inovasi $\rightarrow$ Persepsi

Sumber : Data Terolah, 2019

Hasil analisis sebagaimana yang terdapat pada Tabel 4. dapat diketahui bahwa variabel umur tidak berpengaruh signifikan terhadap persepsi peternak. Variabel umur berpengaruh terhadap variabel persepsi peternak secara sangat signifikan yaitu dengan nilai $\mathrm{P}<0.05(\mathrm{P}=$ 0.001 ). Variabel pendidikan berpengaruh terhadap variabel karakteristik inovasi secara signifikan yaitu dengan nilai $P<0.05$ $(P=0.016)$. Variabel tingkat pendidikan tidak berpengaruh signifikan terhadap persepsi peternak. Variabel pengalaman berpengaruh terhadap variabel karakteristik inovasi secara sangat signifikan yaitu dengan nilai $P<0.05(P=0.000)$. Variabel pengalaman tidak berpengaruh signifikan terhadap variabel persepsi peternak. variabel karakteristik inovasi berpengaruh terhadap variabel persepsi peternak secara sangat signifikan yaitu dengan nilai $P<0.05(P=0.001)$. 
Umur mempengaruhi seseorang dalam menerima sebuah teknologi inovasi. Umur yang berbeda mempengaruhi tahapanyang dilalui oleh peternak dalam mempersepsi suatu teknologi inovasi. Peternak dengan umur lebih dari 61 tahun (17,14\%), penilaiannya akan berbeda dengan peternak dengan umur yang lebih muda. Hal ini sesuai dengan hasil hasil penelitian Sapitri dkk., (2014) menjelaskan bahwa, umur akan mempengaruhi kemampuan fisik dan cara berfikir seseorang. Secara umum dapat dikatakan bahwa semakin tua umur seseorang semakin rendah kemampuan fisik dan produktifitas kerjanya. Demikian sebaliknya, orang yang masih muda dan sehat fisiknya akan memiliki produktifitas kerja yang tinggi.

Tingkat pendidikan tidak berpengaruh secara signifikan terhadap persepsi peternak dikarenakan peternak dalam melalui tahapan mempersepsi teknologi inovasi yaitu menyerap, memahami, dan evaluasi tidak tergantung pada pendidikan yang dimiliki peternak. Tingkat pendidikan tertinggi yang dimiliki peternak itik petelur di Desa Trasan adalah SLTA yaitu sebanyak $22,36 \%$ dan yang terendah adalah SD sebanyak $51,43 \%$ dari umlah keseluruhan responden. Peternak dalam mempersepsi baik yang berpendidikan tinggi ataupun rendah ratarata sama yaitu menjawab bahwa teknologi pembuatan telur asin menggunakan alat pemanas sederhana dalam kategori baik dan dianggap dapat diterima oleh semua kalangan dengan tingkat pendidikan yang berbeda. Hal ini sejalan dengan hasil penelitian Khasanah (2008) yang menyatakan bahwa tinggi rendahnya pendidikan formal responden tidak mempengaruhi responden dalam menerapkanteknologipadakegiatan panen dan pasca panen. Hal ini dikarenakan dengan teknologi panen dan pasca panen yang manual dan sederhana responden tidak membutuhkan keahlian khusus maupun pemahamantinggi.

Lama pengalaman beternak tidak mempengaruhi tahapan dalam mempersepsi suatu teknologi inovasi. Pengalaman beternak yang sebagian besar berpengalaman baru dalam berusaha tani beternak itik petelur yaitu sebesar $85,72 \%$ tidak menentukan penilaian peternak pada setiap tahapan persepsi peternak. Sehingga dapat diketahui bahwa teknologi pembuatan telur asin menggunakan alat pemanas sederhana dinilai baik oleh peternak itik meskipun pengalamannya berbeda-beda. Hal ini sama dengan hasil penelitian Utomo (2012) yang berisi karakteristik internal petani yaitu pengalaman bertani mempunyai hubungan yang lemah dengan semua dimensi variabel persepsi petani terhadap metode SRI. Hal ini berarti pengalaman bertani tidak mempunyai hubungan dengan persepsi petani terhadap metode SRI.

Penilaian peternak terhadap karakteristik inovasi melalui tiga tahapan indikator persepsi terhadap lima aspek karakteristik inovasi diperoleh nilai 3085 dalam kategori baik. Apabila peternak menilai karakteristik dengan nilai yang rendah maka akan mempengaruhi hasil perolehan nilai pada persepsi peternak. Penilaian peternak terhadap karakteristik inovasi sejalan dengan persepsi peternak. Pendapat peternak mengenai karakteristik 
inovasi menentukan persepsi peternak terhadap suatu teknologi inovasi. Pendapat ini didukung dengan hasil penelitian Hasil penelitian Putri (2011) menunjukkan bahwa variabel dari karakateristik suatu inovasi berhubungan dengan tingkat persepsi dan adopsi pertanian padi organik yaitu: 1) segi keuntungan, pertanian organik lebih menguntungkan dibandingkan dengan konvensional. 2) Ada kesesuaian penerapan padi organik dengan kebiasaan petani dalam tahapan usahatani padi. 3) Tingkat kerumitan lebih tinggi dirasakan pada saat permulaan dalam melakukan usahatani padi secara organik. 4) kemungkinan untuk dicoba, peneraparan organik dapat diterapkan dengan lahan yang kecil dan jumlah benih yang lebih sedikit dan modal yang sedikit. 5) kemungkinan untuk diamati, petani sangat dapat merasakan hasilnya seperti rasanya lebih enak dan peningkatan jumlah dan biaya yang dikeluarkan lebih sedikit dibandingkan yang konvensional.

3. Karakteristik Inovasi Memediasi Pengaruh Faktor Internal Terhadap Persepsi Peternak

Variabel eksogen yang berpengaruh terhadap variabel endogen yang dimediasi karakteristik inovasi adalah karakteristik inovasi memediasi pengaruh umur terhadap persepsi peternak. Sehingga pada model ini dapat ditentukan jenis mediasinya, sedangkan variabel yang tidak mendapat pengaruh mediasi tidak dapat ditentukan jenis mediasinya. Pengujian jenis efek mediasi karakteristik inovasi sebagai variabel pemediasi pengaruh antara umur dan persepsi peternak. Nilai direct effects dapat dilihat pada Tabel 5.

Tabel 5. Nilai Direct Effects

\begin{tabular}{lccccc}
\hline Variabel & $\begin{array}{l}\text { Original } \\
\text { sample } \\
(\mathrm{O})\end{array}$ & $\begin{array}{l}\text { Sample } \\
\text { mean } \\
(\mathrm{M})\end{array}$ & $\begin{array}{l}\text { Std } \\
\text { deviation } \\
\text { (STDEV) }\end{array}$ & $\begin{array}{l}T \\
\text { statistics }\end{array}$ & $\begin{array}{l}P \\
\text { value }\end{array}$ \\
\hline Umur $\rightarrow$ Karakteristik inovasi & -0.210 & -0.215 & 0.170 & 1.235 & 0.218 \\
Umur $\rightarrow$ Persepsi & -0.505 & -0.516 & 0.150 & 3.357 & 0.001 \\
Pendidikan $\rightarrow$ Karakteristik inovasi & 0.375 & 0.396 & 0.155 & 2.423 & 0.016 \\
Pendidikan $\rightarrow$ Persepsi & 0.412 & 0.403 & 0.125 & 3.296 & 0.001 \\
Pengalaman $\rightarrow$ Karakteristik inovasi & -0.544 & -0.532 & 0.145 & 3.766 & 0.000 \\
Pengalaman $\rightarrow$ persepsi & -0.087 & -0.089 & 0.168 & 0.515 & 0.607 \\
Karakteristik inovasi $\rightarrow$ Persepsi & 0.518 & 0.540 & 0.151 & 3.444 & 0.001 \\
\hline
\end{tabular}

Sumber : Data Terolah 2019

Selanjutnya melihat nilai indirect effects untuk melihat perubahan nilai dan signifikansinya. Nilai indirect effects hasil analisis menggunakan SmartPLS 3.2.1 dapat dilihat pada Tabel 6. 
Tabel6. Hasil Nilai IndirectEffects

\begin{tabular}{lccccc}
\hline Variabel & $\begin{array}{c}\text { Original } \\
\text { sample (O) }\end{array}$ & $\begin{array}{c}\text { Sample } \\
\text { mean (M) }\end{array}$ & $\begin{array}{c}\text { Std } \\
\text { deviation } \\
\text { (STDEV) }\end{array}$ & T-statistics & $\begin{array}{c}P \\
\text { value }\end{array}$ \\
\hline Umur $\rightarrow$ Persepsi & -0.109 & -0.109 & 0.092 & 1.189 & 0.235 \\
Pendidikan $\rightarrow$ Persepsi & 0.194 & 0.219 & 0.120 & 1.623 & 0.105 \\
Pengalaman $\rightarrow$ persepsi & -0.282 & -0.290 & 0.120 & 2.346 & 0.019 \\
\hline Sunnnyyyyyn
\end{tabular}

Sumber : Data Terolah 2019

Pada hasil analisis direct effects sebagaimana dapat dilihat pada Tabel 24 . umur (X1) terhadap persepsi peternak (Y2) koefisiennya sebesar 0,505 dan signifikan dengan $P$-value $=0.001(P<0.05)$. Hasil analisis indirect effects sebagaimana dapat dilihat pada Tabel 25. menunjukkan koefisien umur (X1) terhadap persepsi peternak (Y2) menurun menjadi 0,109 berubah menjadi tidak signifikan dengan $\mathrm{P}$ value $=0.235(P>0.05)$. Hal ini menunjukkan bentuk full mediation atau dengan kata lain karakteristik inovasi memediasi secara penuh pengaruh faktor internal terhadap persepsi peternak. Hal ini sesuai dengan pendapat Kock (2011) Jika koefisien variabel eksogen $\rightarrow$ variabel endogen nilainya turun dan menjadi tidak signifikan maka bentuk mediasi adalah mediasi penuh (full mediation).

\section{KESIMPULAN}

Persepsi peternak terhadap teknologi pembuatan telur asin menggunakan alat pemanas sederhana adalah baik. Umur (X1) berpengaruh sangat signifikan terhadap persepsi peternak (Y2). Karakteristik inovasi (Y1) berpengaruh signifikan terhadap persepsi peternak (Y2). Pendidikan dan pengalaman berusaha tani berpengaruh signifikan terhadap karakteristik inovasi dan tidak berpengaruh nyata terhadap persepsi peternak. Karakteristik inovasi secara signifikan memediasivariabel umur terhadap persepsi peternak.

\section{DAFTAR PUSTAKA}

Alisa, I.2007. Persepsi Petani Terhadap Inovasi Untuk Menggunakan Pupuk Kompos Kotoran Ternak Produk P4S Bumi Lestari Sragen (Kasus Petani di Desa Gondang Kecamatan Gondang Kabupaten Sragen ). Skripsi. Program Studi Sosial Ekonomi Peternakan, Fakultas Peternakan, Institut Pertanian Bogor, Bogor.

Fachrista, I. A. dan M. Sarwendah.2014. Persepsi Dan Tingkat Adopsi Petani Terhadap Inovasi Teknologi Pengelolaan Tanaman Terpadu Padi Sawah. Agriekonomika ISSN 23019948 volume 3 nomor 1. Balai Pengkajian Teknologi Pertanian Kepulauan Bangka Belitung, Bangka Belitung.

Kementerian Pertanian.2018. Peraturan Menteri Pertanian Republik Indonesia Nomor 03/Permentan/Sm.200/1/2018 Tentang Pedoman Penyelenggaraan Penyuluhan Pertanian. Jakarta. 
Khasanah, W.2008. Hubungan Faktor-

Faktor Sosial Ekonomi Petani Dengan Tingkat Adopsi Inovasi Teknologi Budidaya Tanaman Jarak Pagar (Jatropha Curcas L.) Di Kecamatan Lendah Kabupaten Kulon Progo. Skripsi.Fakultas Pertanian Universitas Sebelas Maret, Solo.

Kock, N.2011. Using WarpPLS in eCollaboration Studies: Mediating Effects, Control and Second Order Variables, and Algorithm Choices. International Journal of eCollaboration, 7(3): 1-13.

Mulia, A.2017. Proses Pembuatan Telur Asin Sebagai Peluang Usaha.Buletin Peternakan Edisi IV 2017 Dinas Peternakan dan Kesehatan Hewan Provinsi. Sulawesi Selatan.

Putri, N.I.2011. Penerapan Teknologi Pertanian Padi Organik di Kampung Ciburuy, Desa Ciburuy, Kecamatan Cigombong, Kabupaten Bogor. [skripsi]. Bogor (ID): Institut Pertanian Bogor.

Schiffman, L. and Kanuk, L.L.2010. Consumer Behavior. 10th Edition. Pearson Prentice Hall, New Jersey.

Surakitti. 2004. Kimia 3 Kelas 3 SMA. Intan Pariwara, Klaten.

Walgito, B.1990. Bimbingan Penyuluhan di Sekolah. Yayasan Penerbitan Fakultas Psikologi, Yogyakarta.

Utomo, P.2012. Persepsi Petani Terhadap Metode Budidaya Padi System Of Rice Intensification (Sri) Di Desa Ringgit Kecamatan Ngombol
Kabupaten

Purworejo.Skripsi.Universitas

Muhammadiyah

Purworejo, 